\title{
小型無人航空機の誘導制御と自律飛行試験*1 \\ Guidance and Control of a Small Unmanned Aerial Vehicle and Autonomous Flight Experiments
}

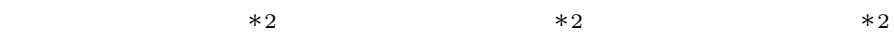 \\ Jin Fujinaga, Hiroshi Tokutake and Shigeru Sunada
}

Key Words : Unmanned Aerial Vehicle, Flight Control, Flight Experiment

\begin{abstract}
This paper describes the development of a fixed-wing small-size UAV and the design of its flight controllers. The developed UAV's wing span is $0.6 \mathrm{~m}$, and gross weight is $0.27 \mathrm{~kg}$. In order to ensure robust performances of the longitudinal and lateral-directional motions of the UAV, flight controllers are designed for these motions with $\mu$-synthesis. Numerical simulations show that the designed controllers attain good robust stabilities and performances, and have good tracking performance for command. After an order-reduction and discretization, the designed flight controllers were implemented in the UAV. A flight test was performed, and the ability of the UAV to fly autonomously, passing over waypoints, was demonstrated.
\end{abstract}

$$
\begin{aligned}
& \text { 記 } \\
& \text { 号 } \\
& C^{n \times m}: n \times m \text { の複素数体 } \\
& e_{\mathrm{el}}, e_{\phi}, e_{p}, e_{q}: \text { 評価出力 } \\
& G_{\text {lon }}, G_{\text {lat }} \text { : 重み関数を含む一般化プラント } \\
& G_{\mathrm{th}}, G_{\mathrm{ail}} \text { : フィードフォワードフィルタ } \\
& g: \text { 重力加速度 } \\
& K_{\mathrm{th}}, K_{\mathrm{ail}} \text { : 経路角コマンド, バンク角コマ } \\
& \text { ンドに対するフィルタゲイン } \\
& K_{\text {lon }}, K_{\text {lat }} \text { : 縦, 横・方向の安定化制御器 } \\
& L / D: \text { 揚抗比 } \\
& L_{\beta}^{\prime}, L_{p}^{\prime}, L_{r}^{\prime}, L_{\delta_{\mathrm{a}}}^{\prime} \text { : 有次元安定微係数 } \\
& M_{u}, M_{\alpha}, M_{q}, M_{\delta_{\mathrm{t}}}, M_{\delta_{\mathrm{e}}} \text { : 有次元安定微係数 } \\
& N_{\beta}^{\prime}, N_{p}^{\prime}, N_{r}^{\prime}, N_{\delta_{\mathrm{a}}}^{\prime} \text { : 有次元安定微係数 } \\
& P_{\mathrm{ev}}: \text { エレボンのダイナミクス } \\
& p: \text { ロール角速度 } \\
& q: \text { ピッチ角速度 } \\
& \boldsymbol{R}: \text { 実数体 } \\
& r: \exists \text { 一角速度 } \\
& U_{0}, u: \text { 釣り合い点での } x \text { 軸方向速度， } \\
& x \text { 軸方向速度 } \\
& u_{\mathrm{el}}: \text { エレボンダイナミクスへの入力 } \\
& W_{0} \text { : 釣り合い点での } z \text { 軸方向速度 } \\
& W_{\text {gust }} \text { : ガスト入力の重み関数 } \\
& W_{p}, W_{q}, W_{\phi}: \text { 重み関数 } \\
& W_{p \text { noise }}, W_{q \text { noise }}, W_{r \text { noise }} \text { : 角速度計ノイズの重み関数 } \\
& W_{u}: \text { エレボンダイナミクス入力側 }
\end{aligned}
$$

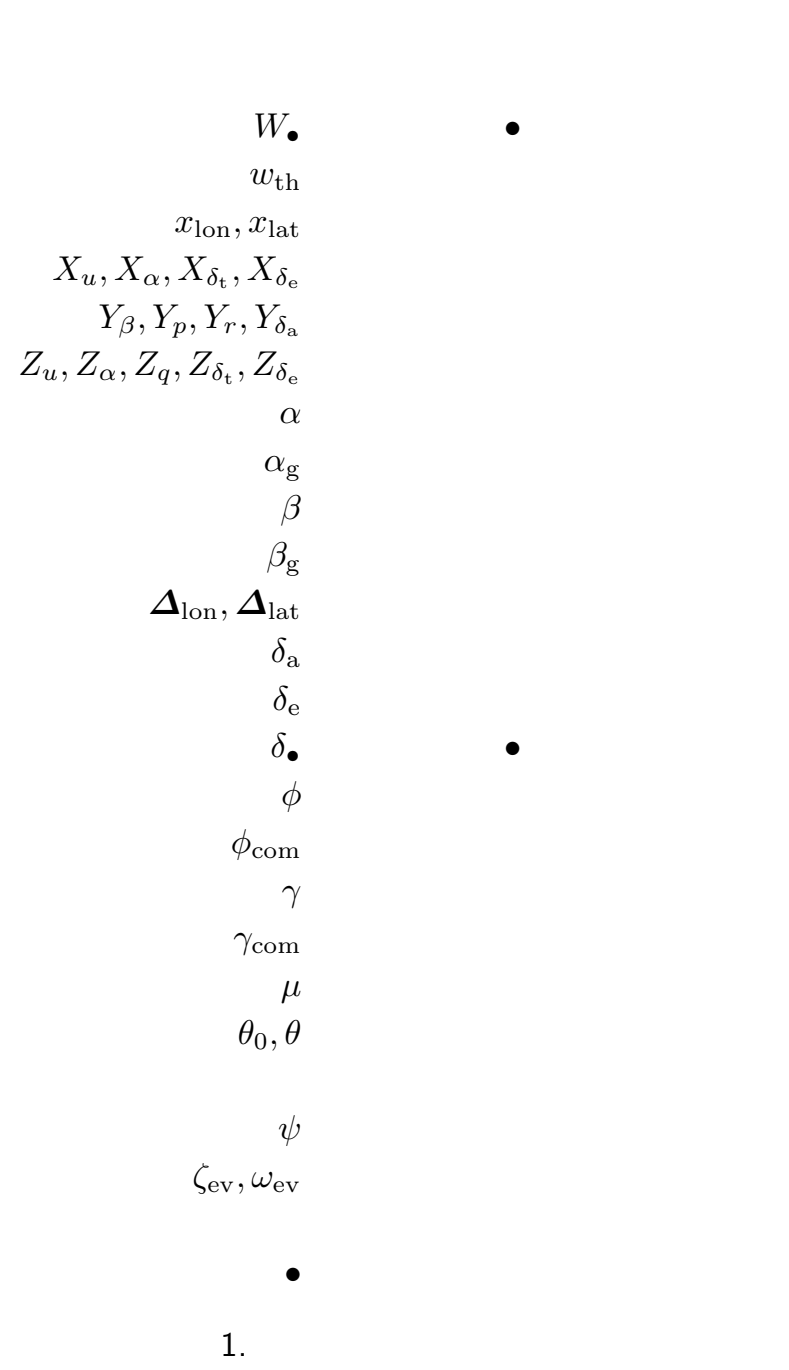

1. はじめに

近年, 無人航空機 (UAV, Unmanned Aerial Vehicle) 
の研究開発が盛んに行われており1 33), 実用化された機体も 存在する . 光れら開発されているUAV の多くがメートル サイズのものであり，比較的長時間・長距離のミッション を想定している . また重量も数キログラム以上のものがほ とんどであり，携帯性や安全性の観点から小型，軽量な機 体開発を行うことは非常に有意義である. わが国における $1 \mathrm{~m}$ 以下のUAV として, (株) 日立製作所と川田工業 (株) が開発した小型自律飛行体システムがあげられる ${ }^{4)}$. これ はスパン $0.6 \mathrm{~m}$, 全長 $0.45 \mathrm{~m}$, 質量約 $0.4 \mathrm{~kg}$ の固定翼型の UAV である. 本研究グループは現行のUAV と比べてより 短距離，短時間のミッションを想定し，スパン $0.6 \mathrm{~m}$, 質量 $0.27 \mathrm{~kg}$ の比較的小型軽量な固定翼型 UAV を開発した . こ のUAV は軽量であるため比較的低速で飛行でき，安全性 が高い．しかし低速で飛行する軽量の機体は風外乱に弱い ため，十分な安定性を備えた制御系を実装することが必要 となる．またUAV の自律飛行を可能にするためには，機 体構造の開発だけではなく，航法・誘導・制御系の高性能 化も必要である .

そこでまず機体ダイナミクスを精度良くモデル化し，モ デルベースのロバスト制御則を用いて高い安定性と性能を 持つ安定化制御系を設計した .さらに指定したウェイポイ ントに沿って飛行する経路コマンドを生成する航法誘導系 も設計し, 安定化制御系とあわせて自律飛行システムを構 築した。

本稿では制御系設計，航法誘導系の構成，汎用制御基板 について述べる．光して乥れらを実装した自律飛行試験を 行い性能を評価する。

\section{2. 機 体 の 概 略}

第 1 図に開発した機体の外観を示す. 軽量化のために機 体は主に発泡スチロールで製作し，プロペラを機体上面に 配置することで衝突時の危害を低減させている．また低速 飛行を実現するために翼面積の大きな全翼機形状とした . 主翼スパンは $60 \mathrm{~cm}$ であり, 垂直安定板を備え, エレボン とプロペラ推力で操縦を行う．機体の胴体部にアビオニク スを搭載し機体を誘導制御する.これら機体の主な特徵を 第 1 表に示す.

\section{3. 制 御 装 置}

自律飛行に必要なセンサや誘導制御器を実装するマイコ ンなどは,特に開発機体のような小型機に用いる場合には小 型軽量であることが必要である . また今後さまざまなプログ ラムを実装し飛行試験やミッションを遂行することを考える と, プログラミングの自由度が高く, 多くの機器を接続でき る拡張性を備えた制御用ハードウェアか望ましい．しかし現 在このような特徵を備えた市販の制御用ハードウェアは存在 しない，乥こで自律飛行体を用途として想定した沉用制御基 板を新たに開発した (第 2 図).大きさは $75 \mathrm{~mm} \times 55 \mathrm{~mm}$ ， 重さは $29 \mathrm{~g}$ である. 弚の特徵を第 2 表に示す. 基板上には 角速度計および加速度計か実装され 3 軸方向の角速度, 加 速度が測定可能である.GPS アンテナや地磁気方位計など

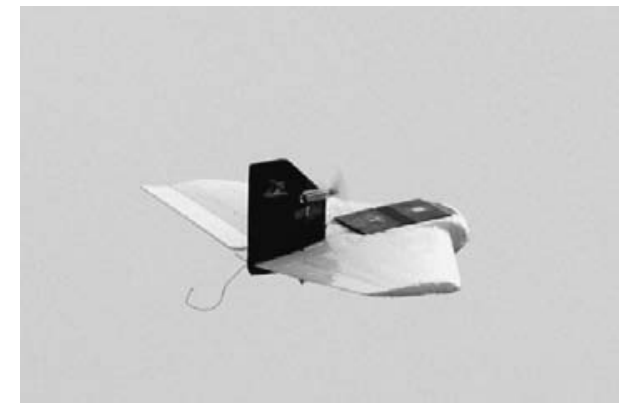

(a) 外観

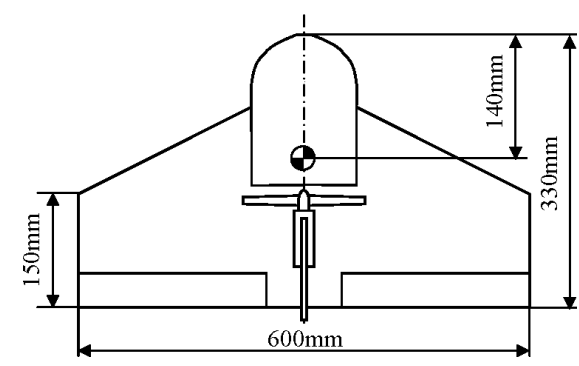

(b) 平面図

第 1 図 開発機体概略

\begin{tabular}{ll} 
& 第 1 表 機体特徵 \\
\hline スパン & $0.6 \mathrm{~m}$ \\
アスペクト比 & 2.67 \\
質量 & $0.27 \mathrm{~kg}$ \\
バッテリ & リチウムポリマバッテリ \\
飛行時間 & 15 分 $(6.5 \mathrm{~m} / \mathrm{s}$ で飛行時 $)$ \\
飛行速度 & $6 \sim 11 \mathrm{~m} / \mathrm{s}$ \\
\hline
\end{tabular}

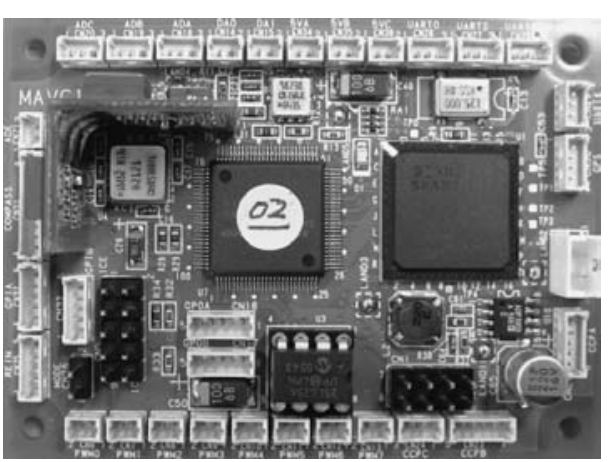

第 2 図 小型汎用制御基板

の入力端子も備えられている . また接続された機器との入 出力を行い制御用プログラムをリアルタイムで実行するミ ドルウェアもあわせて開発した .これらのハードウェアおよ びソフトウェアは (株) ワイズ・ラブとの共同開発である .

\section{4. 姿勢安定化制御器の設計}

4.1 風洞試験 風洞試験を実施し機体の空力特性を測 定した (第 3 図). 風速, 迎え角, 横滑り角, 舵角, プロ ペラ回転数を変化させ機体に働く 6 分力を測定した . これ らの測定結果より，機体に作用する空気力ゃトリム飛行条 件, 静的な空力微係数が求められる. 動的な空力微係数は 
第 2 表 開発基板特徵

\begin{tabular}{ll}
\hline CPU & 日立, HD64F3069 \\
FPGA & Xilinx, XC2S200FG256 \\
角速度計 & Analog Devices, ADXRS300 ×3 \\
加速度計 & Analog Devices, ADXL210JE $\times 2$ \\
EEPROM & $32 \mathrm{kbyte}$ \\
A/D & $6 \mathrm{ch}$ \\
D/A & $2 \mathrm{ch}$ \\
パルス入 & $10 \mathrm{ch}$ \\
$\mathrm{PWM}$ 出カ & $8 \mathrm{ch}$ \\
$\mathrm{I} / \mathrm{O}$ & $8 \mathrm{ch}$ \\
$\mathrm{UART}$ & $4 \mathrm{ch}$ \\
GPS 入力 & $1 \mathrm{ch}$ \\
地磁気方位計入カ & $1 \mathrm{ch}$ \\
ロータリエンコーダ入カ & $1 \mathrm{ch}$ \\
$5 \mathrm{~V}$ 出カ & $3 \mathrm{ch}$ \\
\hline
\end{tabular}

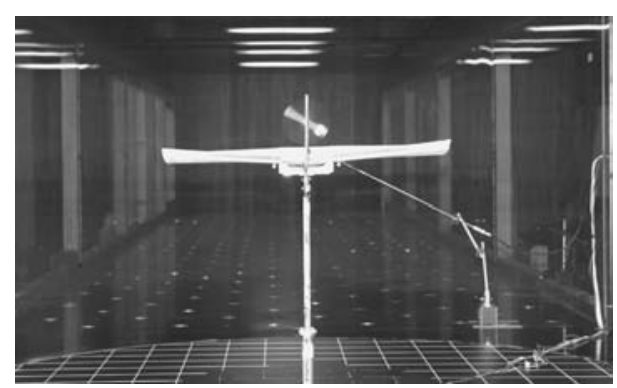

第 3 図 風洞試験

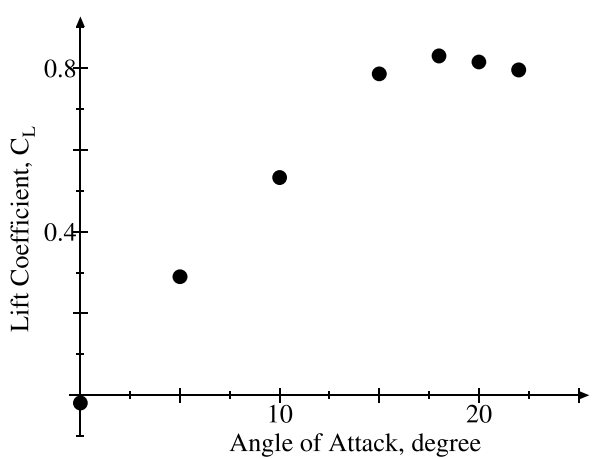

第 4 図 迎え角に対する揚力係数

文献 5)，6）の手法に従い推算した . 測定した空力特性の例 として，迎え角と全機揚力係数の関係を第 4 図に，全機揚 力係数と全機抗力係数の関係を第 5 図に示す.第 4 図から 迎え角が約 18 度付近で最大揚力が発生することがわかる． また第 5 図から揚抗比も約 15 度付近で最大となることが わかる .

4.2 線形化運動方程式へのモデル化 風洞試験結果を踏 まえて, 釣り合い点周りに線形化されたモデルに対して制 御系を設計する . 線形化された運動方程式を以下に示す ${ }^{5,6)}$. 縦方向線形化運動方程式

$$
\begin{aligned}
& \dot{x}_{\text {lon }}=A_{\text {lon }} x_{\text {lon }}+B_{1 \mathrm{lon}} w_{\text {lon }}+B_{2 \mathrm{lon}} \delta_{\mathrm{e}} \\
& y_{\text {lon }}=C_{\text {lon }} x_{\text {lon }}+D_{1 \mathrm{lon}} w_{\mathrm{lon}}
\end{aligned}
$$

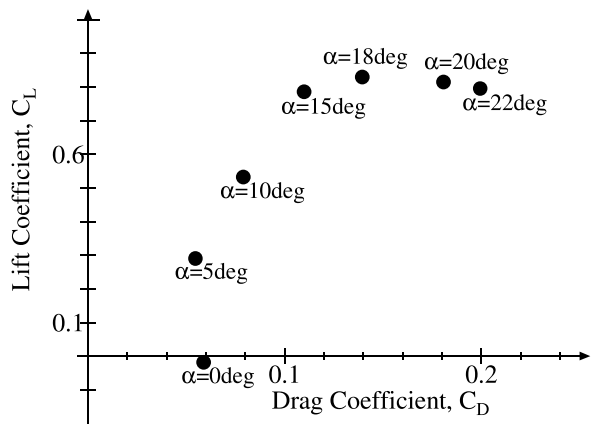

第 5 図 抗力係数と揚力係数の関係

$$
\begin{aligned}
& x_{\text {lon }}=\left[\begin{array}{llll}
u & \alpha & q & \theta
\end{array}\right]^{\mathrm{T}}, \quad w_{\text {lon }}=\left[\begin{array}{ll}
\alpha_{\mathrm{g}} & w_{\mathrm{th}}
\end{array}\right]^{\mathrm{T}} \\
& A_{\text {lon }}=\left[\begin{array}{cccc}
X_{u} & X_{\alpha} & -W_{0} & -g \cos \theta_{0} \\
Z_{u} / U_{0} & Z_{\alpha} / U_{0} & \left(U_{0}+Z_{q}\right) / U_{0} & -g \sin \theta_{0} / U_{0} \\
M_{u} & M_{\alpha} & M_{q} & 0 \\
0 & 0 & 1 & 0
\end{array}\right] \\
& B_{1 \text { lon }}=\left[\begin{array}{cc}
X_{\alpha} & X_{\delta_{\mathrm{t}}} \\
Z_{\alpha} / U_{0} & Z_{\delta_{\mathrm{t}}} / U_{0} \\
M_{\alpha} & M_{\delta_{\mathrm{t}}} \\
0 & 0
\end{array}\right] \\
& B_{2 l o n}=\left[\begin{array}{c}
X_{\delta_{\mathrm{e}}} \\
Z_{\delta_{\mathrm{e}}} / U_{0} \\
M_{\delta_{\mathrm{e}}} \\
0
\end{array}\right] \\
& C_{\text {lon }}=\left[\begin{array}{cccc}
0 & 0 & 1 & 0 \\
0 & 0 & 0 & 0
\end{array}\right], \quad D_{1 \text { lon }}=\left[\begin{array}{ll}
0 & 0 \\
0 & 1
\end{array}\right]
\end{aligned}
$$

横・方向線形化運動方程式

$$
\begin{aligned}
& \dot{x}_{\text {lat }}=A_{\text {lat }} x_{\text {lat }}+B_{1 \text { lat }} w_{\text {lat }}+B_{2 \text { lat }} \delta_{\mathrm{a}} \\
& y_{\text {lat }}=C_{\text {lat }} x_{\text {lat }} \\
& x_{\text {lat }}=\left[\begin{array}{lll}
\beta & p & r
\end{array}\right]^{\mathrm{T}}, \quad w_{\text {lat }}=\left[\beta_{\mathrm{g}}\right]^{\mathrm{T}} \\
& A_{\text {lat }}=\left[\begin{array}{cc}
Y_{\beta} / U_{0} & \left(W_{0}+Y_{p}\right) / U_{0} \\
L_{\beta}^{\prime} & L_{p}^{\prime} \\
N_{\beta}^{\prime} & N_{p}^{\prime} \\
0 & 1
\end{array}\right. \\
& \left.\begin{array}{cc}
\left(Y_{r}-U_{0}\right) / U_{0} & g \cos \theta_{0} / U_{0} \\
L_{r}^{\prime} & 0 \\
N_{r}^{\prime} & 0 \\
\tan \theta_{0} & 0
\end{array}\right] \\
& B_{1 \text { lat }}=\left[\begin{array}{c}
Y_{\beta} / U_{0} \\
L_{\beta}^{\prime} \\
N_{\beta}^{\prime} \\
0
\end{array}\right], \quad B_{2 \text { lat }}=\left[\begin{array}{c}
Y_{\delta_{\mathrm{a}}} / U_{0} \\
L_{\delta_{\mathrm{a}}}^{\prime} \\
N_{\delta_{\mathrm{a}}}^{\prime} \\
0
\end{array}\right] \\
& C_{\text {lat }}=\left[\begin{array}{llll}
0 & 1 & 0 & 0 \\
0 & 0 & 1 & 0
\end{array}\right]
\end{aligned}
$$

これらの運動方程式には機体に作用する風外乱 $\left(\alpha_{\mathrm{g}}, \beta_{\mathrm{g}}\right)$ が加えられている.またロール角速度，ピッチ角速度，ヨー 
角速度が，機体に搭載された角速度計で則定可能である.縦 の運動方程式には，推カコマンド $\delta_{\mathrm{t}}$ がピッチ運動に与え る影響を観測可能な外乱として含めている .

4.3 フィードバック制御系設計問題の定式化 開発機体 は小型軽量で飛行速度も低いことから，風外乱の影響を受 けやすい，また制御系設計対象には複数の不確かさが存在 すると考えられる．従って制御対象をなるべく正確にモデ ル化し, 必要なロバス卜安定性と性能を最大限確保するこ とが必要となる．乥こでモデルベースのロバスト制御理論 である $\mu$ 設計手法7) を採用し，十分な安定性と性能を確保 することを目指した . 以下に考慮した設計条件を記述する

[安定微係数の不確かさ] 見積もつた安定微係数の誤差 を，乗法的な不確かさで定式化する .ここで右肩の“0”は 各安定微係数のノミナル值を表す.

縦方向安定微係数

$$
\begin{aligned}
& {\left[\begin{array}{ccc}
X_{u} & X_{\alpha} & X_{q} \\
Z_{u} & Z_{\alpha} & Z_{q} \\
M_{u} & M_{\alpha} & M_{q}
\end{array}\right]} \\
& =\left[\begin{array}{cc}
\left(1+W_{X_{u}} \delta_{X_{u}}\right) X_{u}^{0} & \left(1+W_{X_{\alpha}} \delta_{X_{\alpha}}\right) X_{\alpha}^{0} \\
\left(1+W_{Z_{u}} \delta_{Z_{u}}\right) Z_{u}^{0} & \left(1+W_{Z_{\alpha}} \delta_{Z_{\alpha}}\right) Z_{\alpha}^{0} \\
\left(1+W_{M_{u}} \delta_{M_{u}}\right) M_{u}^{0} & \left(1+W_{M_{\alpha}} \delta_{M_{\alpha}}\right) M_{\alpha}^{0}
\end{array}\right.
\end{aligned}
$$

$$
\left.\begin{array}{c}
0 \\
\left(1+W_{Z_{q}} \delta_{Z_{q}}\right) Z_{q}^{0} \\
\left(1+W_{M_{q}} \delta_{M_{q}}\right) M_{q}^{0}
\end{array}\right]
$$

横・方向安定微係数

$$
\begin{gathered}
{\left[\begin{array}{ccc}
Y_{\beta} & Y_{p} & Y_{r} \\
L_{\beta}^{\prime} & L_{p}^{\prime} & L_{r}^{\prime} \\
N_{\beta}^{\prime} & N_{p}^{\prime} & N_{r}^{\prime}
\end{array}\right]} \\
=\left[\begin{array}{cc}
Y_{\beta}^{0} & Y_{p}^{0} \\
\left(1+W_{L_{\beta}^{\prime}} \delta_{L_{\beta}^{\prime}}\right) L_{\beta}^{\prime 0} & \left(1+W_{L_{p}^{\prime}} \delta_{L_{p}^{\prime}}\right) L_{p}^{\prime 0} \\
\left(1+W_{N_{\beta}^{\prime}} \delta_{N_{\beta}^{\prime}}\right) N_{\beta}^{\prime 0} & \left(1+W_{N_{p}^{\prime}} \delta_{N_{p}^{\prime}}\right) N_{p}^{\prime 0} \\
& \left(1+W_{Y_{r}} \delta_{Y_{r}}\right) Y_{r}^{0} \\
& \left(1+W_{L_{r}^{\prime}} \delta_{L_{r}^{\prime}}\right) L_{r}^{\prime 0} \\
& \left(1+W_{N_{r}^{\prime}} \delta_{N_{r}^{\prime}}\right) N_{r}^{\prime 0}
\end{array}\right]
\end{gathered}
$$

[アクチュエータダイナミクス] エレボンのアクチュエー タダイナミクスを, ステップ応答試験を行い次の 2 次式で モデル化した .

$$
\begin{aligned}
& P_{\mathrm{ev}}=\frac{\omega_{\mathrm{ev}}^{2}}{s^{2}+2 \zeta_{\mathrm{ev}} \omega_{\mathrm{ev}} s+\omega_{\mathrm{ev}}^{2}} \\
& \zeta_{\mathrm{ev}}=0.8, \quad \omega_{\mathrm{ev}}=20 \mathrm{rad} / \mathrm{s}
\end{aligned}
$$

また , アクチュエータダイナミクスに乗法的不確かさが存 在するとし，光の重み関数を次式で定義する.

$$
W_{u}=0.3 \frac{0.3 s+1}{0.05 s+1}
$$

[ガストモデル] 機体に加わるガストの周波数特性を次
式でモデル化する .

$\alpha_{\mathrm{g}}, \beta_{\mathrm{g}} \in\left\{W_{\text {gust }} \eta_{\text {gust }}: W_{\text {gust }}=\frac{0.3}{s / 2+1},\left\|\eta_{\text {gust }}\right\|_{2} \leq 1\right\}$

[センサノイズ］ ロール角速度，ピッチ角速度，ヨー角速 度の測定値に加わるセンサノイズの周波数特性を，次式で モデル化する .

$W_{\text {pnoise }}=W_{\text {qnoise }}=W_{r \text { noise }}=0.3 \frac{2.6 s^{2}+77.5 s+600}{s^{2}+50 s+600}$

[推力によるピッチ角外乱] 誘導則からの指令により発生 する推力は縦の運動には外乱として働く. 誘導則からの推 力指令の帯域は低いものと考え, 周波数特性を以下のよう に定式化する .

$$
w_{\mathrm{th}} \in\left\{W_{\mathrm{th}} \eta_{\mathrm{th}}: W_{\mathrm{th}}=0.3 \frac{0.01 s+1}{0.5 s+1},\left\|\eta_{\mathrm{th}}\right\|_{2} \leq 1\right\}
$$

[舵角の低減化] 舵角の飽和を防ぐために舵角を制御量 として評価する . 光の制御量に乗ずる重み関数を次のよう に定式化する .

$$
e_{\mathrm{el}}=W_{\mathrm{el}} u_{\mathrm{el}}=\frac{1}{0.25} \frac{1 / 40 s+1}{1 / 70 s+1} u_{\mathrm{el}}
$$

[角速度応答の低減化] 外乱に対する角速度応答を低減

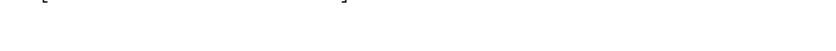
とする .

$$
e_{q}=W_{q} q, \quad e_{p}=W_{p} p, \quad e_{\phi}=W_{\phi} \phi
$$

これらの設計条件と (1)〜 (4) 式をあわせて , 縦および横・ 方向運動の一般化プラントを構築する (第 6,7 図).

図中で $W_{i}, i=1, \ldots, 8$ は, 空力特性の不確かさを表す 重み関数である . これらの不確かさを持つ一般化プラント を第 8,9 図のようにLFT 形式で表し，次の $\mu$ 設計問題 を解くことで縦，横・方向のコントローラ $K_{\text {lon }}, K_{\text {lat }}$ を 求めた .

縦方向 $\mu$ 設計問題

$$
\text { Find } K_{\text {lon }} \text { such that } \sup _{\omega \in \boldsymbol{R}} \mu_{\boldsymbol{\Delta}_{\text {lon }}}\left(\mathcal{F}_{l}\left(G_{\text {lon }}, K_{\text {lon }}\right)\right) \leq 1
$$

横・方向 $\mu$ 設計問題

Find $K_{\text {lat }}$ such that $\sup _{\omega \in \boldsymbol{R}} \mu_{\boldsymbol{\Delta}_{\text {lat }}}\left(\mathcal{F}_{l}\left(G_{\text {lat }}, K_{\text {lat }}\right)\right) \leq 1$ ここで，

$$
\begin{aligned}
& \boldsymbol{\Delta}_{\text {lon }}=\left[\begin{array}{cccc}
\delta_{1} & & & 0 \\
& \ddots & & \\
& & \delta_{9} & \\
0 & & & \boldsymbol{\Delta}_{p}
\end{array}\right] \\
& \delta_{i} \in \boldsymbol{R} \quad(i=1, \cdots, 8), \quad \delta_{9} \in \boldsymbol{C}, \quad \boldsymbol{\Delta}_{p} \in \boldsymbol{C}^{3 \times 2} \\
& \boldsymbol{\Delta}_{\text {lat }}=\left[\begin{array}{cccc}
\delta_{1} & & & 0 \\
& \ddots & & \\
& & \delta_{8} & \\
0 & & & \boldsymbol{\Delta}_{p}
\end{array}\right] \\
& \delta_{i} \in \boldsymbol{R} \quad(i=1, \cdots, 7), \quad \delta_{8} \in \boldsymbol{C}, \quad \boldsymbol{\Delta}_{p} \in \boldsymbol{C}^{3 \times 3}
\end{aligned}
$$




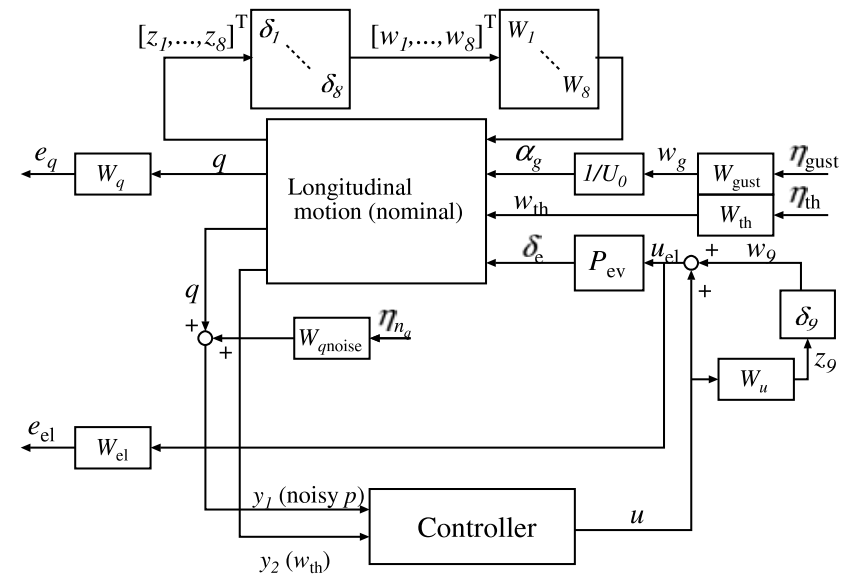

第 6 図 縦の一般化プラント

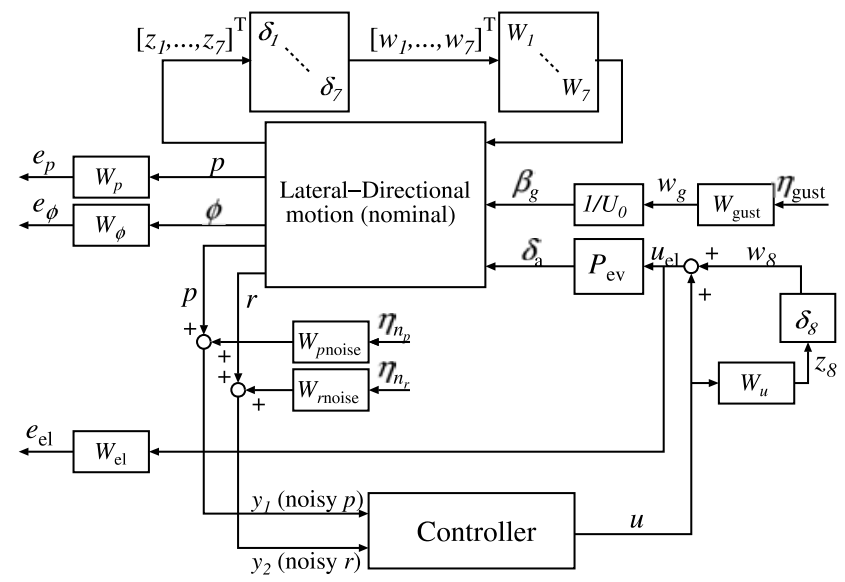

第 7 図 横・方向の一般化プラント

である

これらの制御系設計問題を複数の設計点について数值計 算ソフトウェア 8$)$ を用いて解き，得られたコントローラを スケジューリングやスイッチングして使用することで, 幅 広い飛行領域か確保できる，光の飛行領域の中でも低速側 は, 突風外乱の影響を受けやすい飛行状態である，乥こで 今回は飛行可能な領域の中で低速でのトリム点を設計点に 選び, コントローラの評価を行った.設計点は迎え角 15 度， 速度 $6.2 \mathrm{~m} / \mathrm{s}$ での水平直線飛行とした .

4.4 フィードフォワードフィルタ設計 航空機を目的の 地点に誘導するためには，機体にコマンドを与え，弚れに 追従させることが必要となる．乥こで, フィードバック制 御器によってロバスト安定化されたフィードバックループ に対して, 縦運動の場合には経路角を, 横・方向運動の場 合にはバンク角をコマンドとして与える.第 10,11 図に 示すように, 経路角コマンドはフィードフォワードフィル タを介してスロットル入力に , バンク角コマンドはエルロ ン入力に印加させる．機体の横・方向のダイナミクスは制 御器により安定化されているため, エルロンに有界な信号 を加えると機体は定常旋回を行う. 従って加法的なエルロ ン入カをバンク角コマンドとして用いた .

フィルタは適切なゲインを持つ時定数 $0.5 \sim 1.5 \mathrm{~s}$ の一次

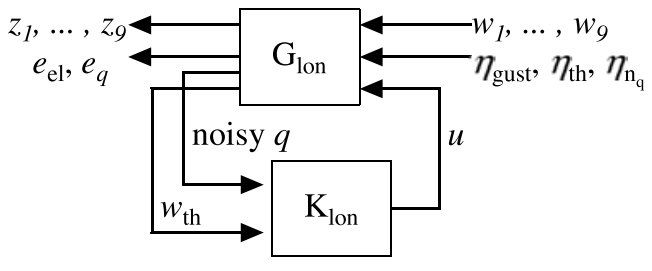

第8図 LFT (縦)

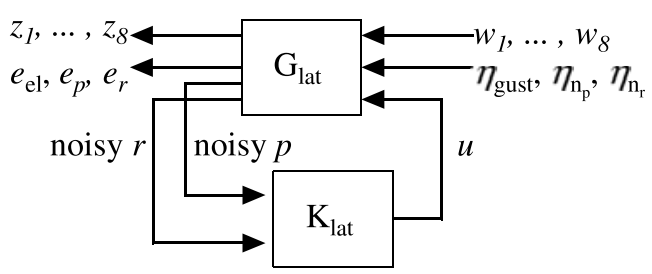

第9図 LFT (横·方向)

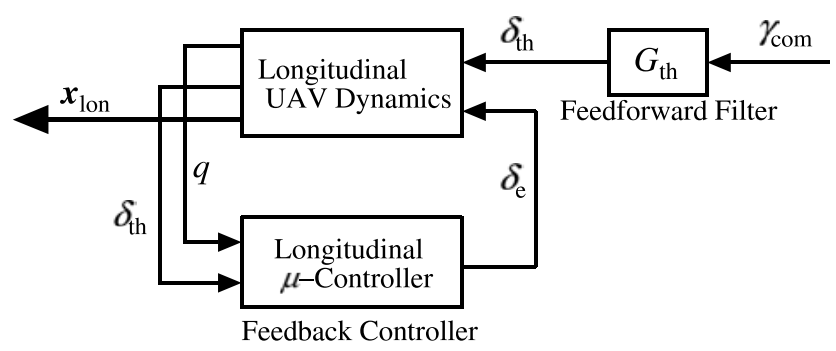

第 10 図＼cjkstart縦運動におけるフィードフォワードフィルタ

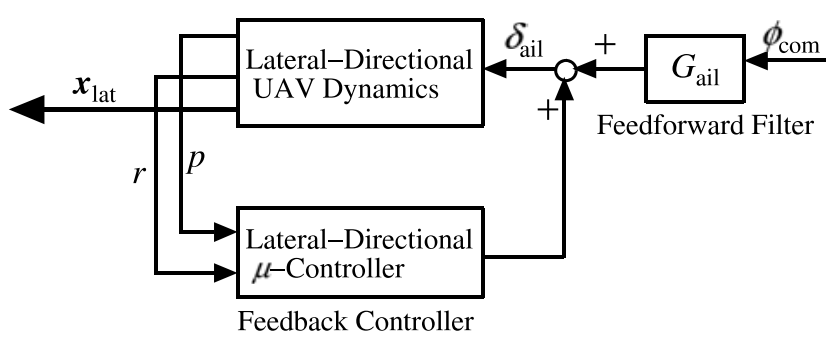

第 11 図＼cjkstart横・方向運動におけるフィードフォワードフィルタ

遅れ系とした ·採用したフィルタを以下に示す．

$$
G_{\mathrm{th}}=\frac{K_{\mathrm{th}}}{1.5 s+1}, \quad G_{\text {ail }}=\frac{K_{\text {ail }}}{0.5 s+1}
$$

ここで, $K_{\mathrm{th}}, K_{\text {ail }}$ は光れ㢳れ縦，横・方向のフィードフォ ワードループにおける, スロットル入力から経路角, エル ロン入カからバンク角の定常值の逆数である.

$$
\text { 5. 数值シミュレーション }
$$

設計した安定化制御器を評価するために数值シミュレー ションを実施した . 第 3 表に開発機体の諸元と想定した卜 リム飛行状態を示す．風洞試験結果と文献 5) および 6)よ り，トリム状態における (1)，(2) 式および (3)，(4) 式中の 行列の値は以下のようになった . 


$$
\begin{aligned}
& A_{\text {lon }}= {\left[\begin{array}{cccc}
-2.31 & -5.61 & 0 & -9.80 \\
0.06 & -5.28 & 0.94 & 0 \\
7.05 & -29.80 & -0.72 & 0 \\
0 & 0 & 1 & 0
\end{array}\right] } \\
& B_{1 \text { lon }}= {\left[\begin{array}{cc}
-5.61 & 5.36 \\
-5.28 & -0.65 \\
-29.80 & -18.31 \\
0 & 0
\end{array}\right] } \\
& B_{2 \text { lon }}= {\left[\begin{array}{c}
-2.73 \\
-2.35 \\
-28.72 \\
0
\end{array}\right] } \\
& \text { 第3 表 開発機体の諸元 }
\end{aligned}
$$

\begin{tabular}{|c|c|}
\hline 質量 & $0.27 \mathrm{~kg}$ \\
\hline 慣性モーメント， $I_{x x}$ & $1.05 \times 10^{-2} \mathrm{~kg} \cdot \mathrm{m}^{2}$ \\
\hline$I_{y y}$ & $1.30 \times 10^{-2} \mathrm{~kg} \cdot \mathrm{m}^{2}$ \\
\hline$I_{z z}$ & $6.96 \times 10^{-3} \mathrm{~kg} \cdot \mathrm{m}^{2}$ \\
\hline$I_{x z}$ & $6.25 \times 10^{-4} \mathrm{~kg} \cdot \mathrm{m}^{2}$ \\
\hline トリム飛行状態 & 水平直線飛行 \\
\hline トリム迎え角， $\alpha$ & 15 degrees \\
\hline トリム機速， $U_{0}$ & $6.2 \mathrm{~m} / \mathrm{s}$ \\
\hline
\end{tabular}
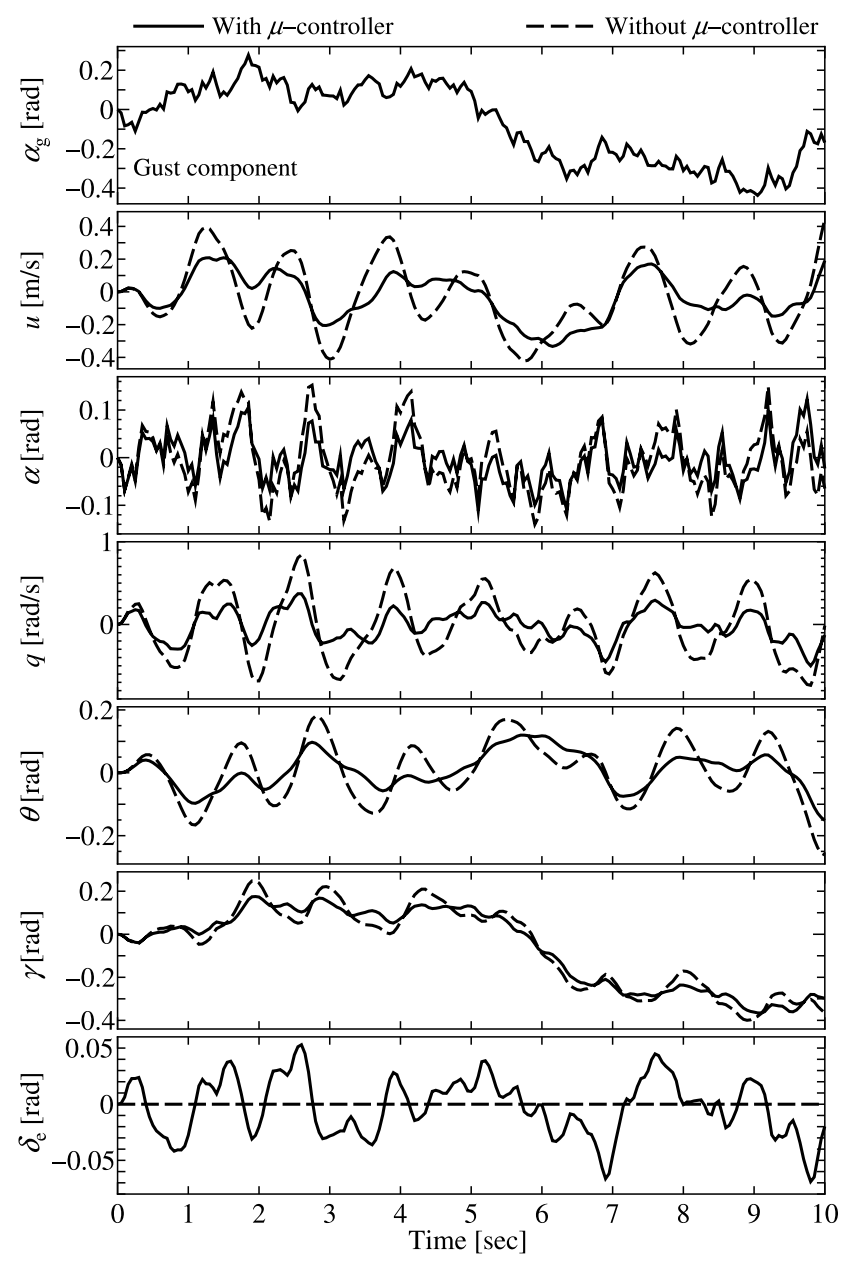

第 12 図風外乱に対する応答 (縦の運動)

$$
\begin{aligned}
& A_{\text {lat }}=\left[\begin{array}{cccc}
-0.83 & 0.26 & -0.99 & 1.53 \\
-61.06 & -6.96 & 0.30 & 0 \\
9.93 & 0.40 & 0.06 & 0 \\
0 & 1 & 0.27 & 0
\end{array}\right] \\
& B_{1 \text { lat }}=\left[\begin{array}{c}
-0.83 \\
-61.06 \\
9.93 \\
0
\end{array}\right], \quad B_{2 \text { lat }}=\left[\begin{array}{c}
-0.10 \\
45.53 \\
9.52 \\
0
\end{array}\right]
\end{aligned}
$$

この数值例を用い，機体の空力モデルに不確かさを含めな いノミナルモデルについてシミュレーションを実施した .

まず迎え角，横滑り角に対する持続的な風外乱 $\left(\alpha_{\mathrm{g}}, \beta_{\mathrm{g}}\right)$ を光れ光れ縦，横・方向の運動方程式に入力し，安定化制御 器がある場合，ない場合について機体の運動をシミュレー ションした (第 12,13 図)。

第 12 図から, 安定化制御器により, ピッチ角速度の応答 をピーク值で比較すると，およ光 $40 \%$ 程度抑制されてい ることが確認できる．よってこれらの風外乱に対して，縦 の安定化制御器は有効に作用していることがわかる．一方 第 13 図から, 横・方向の安定化制御器は縦の場合ほど風外 乱に対する抑制効果はないものの，ロール角，ロール角速 度の応答は低減されていることが確認できる．

つぎに安定化制御器を組み込んだインナーループの，ス テップ状のコマンド入力に対する応答をシミュレーションし た .コマンドの大きさは, 経路角コマンド $\gamma_{\mathrm{com}}=0.1 \mathrm{rad}$ ，

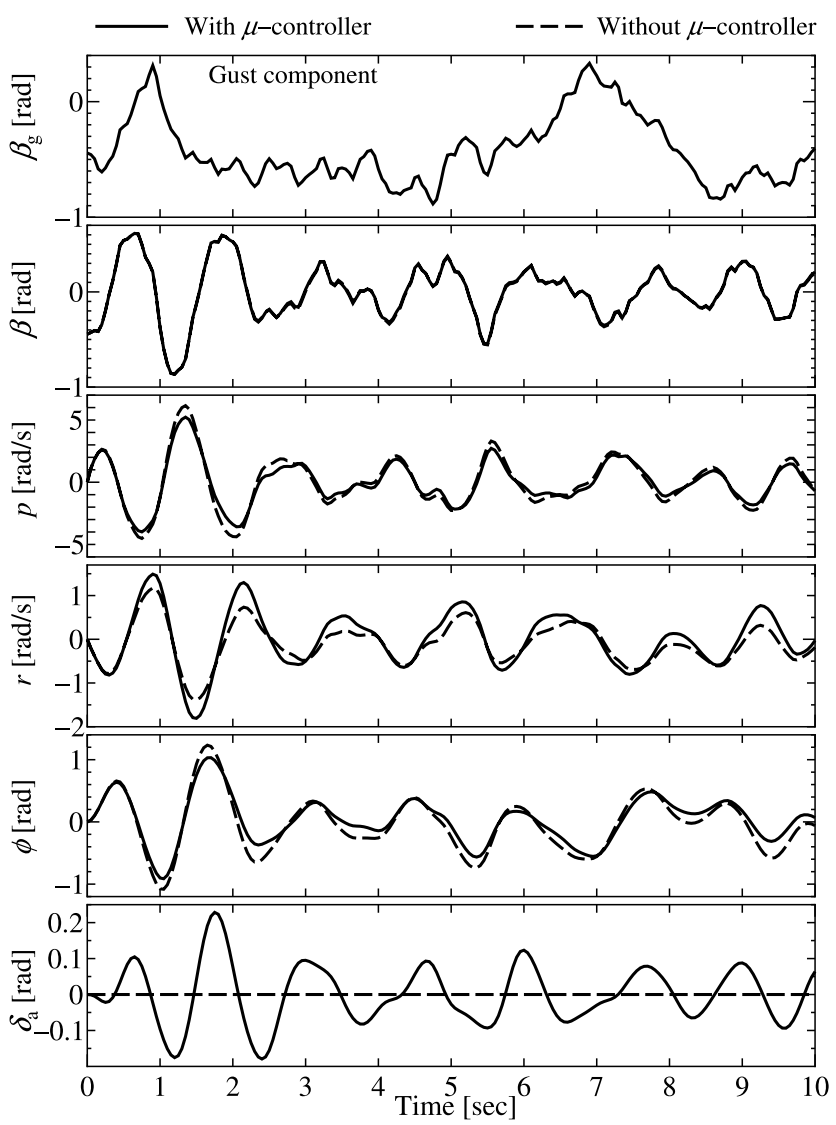

第 13 図 風外乱に対する応答 (横・方向の運動) 


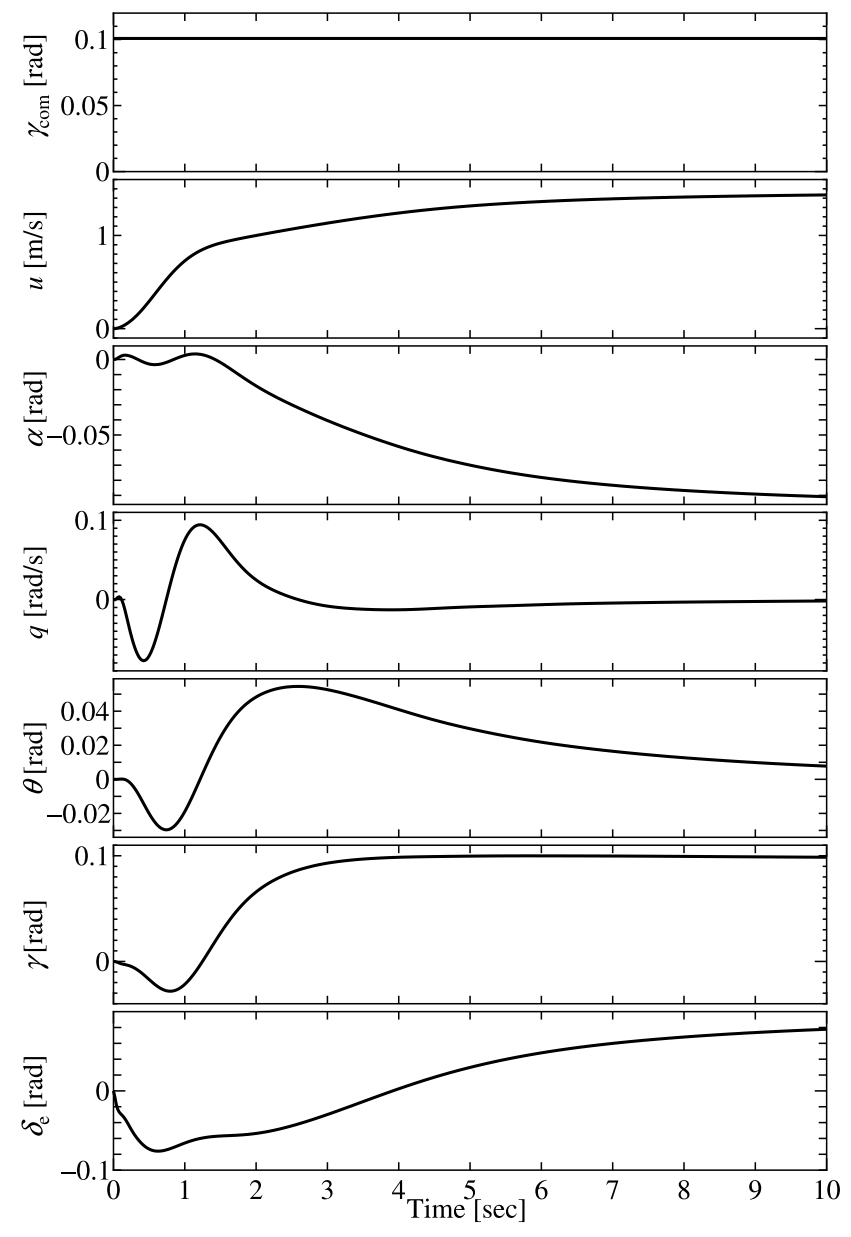

第 14 图 経路角コマンドのステップ入力に対する応答

バンク角コマンド $\phi_{\mathrm{com}}=0.3 \mathrm{rad}$ とした . 第 14 図に経路 角コマンド入力に対する応答を示す . コマンド入力に対し て経路角は微小な逆応答を示すものの, 機体の振動は安定 化制御器により抑制されており機体の経路角は 5 ～6 秒ほ どで定常值に漸近し，コマンドによく追従していることが わかる .

第 15 図にバンク角コマンド入力に対する応答を示す.横・ 方向の運動方程式 ((3)，(4) 式) における $A_{\text {lat }}$ の固有値 は $-6.25,-0.773 \pm i 4.578,0.203$ であるので, 横・方向 の運動は不安定である. 弚のため設計した安定化制御器を 用いない場合，エルロンのステップ入力に対して機体の応 答は発散する.第 15 図より安定化制御器により機体は安 定化され，機体のバンク角応答は $3 \sim 4$ 秒ほどで目標值に 収束することがわかり，制御器の有効性が確認できる．

\section{6. 航 法誘導系}

$\mu$ 設計手法て設計された安定化制御器と機体ダイナミク スで構成されるインナーループに対して, 設定された経路 に沿った飛行を実現する経路角コマンドとバンク角コマン ドを生成するシステムを PID 制御を用いて構成した .

ます現在の機体位置および高度と機体の進行方向を GPS ， 高度計，方位計を用いて計測する．乥してあらかじめ設定
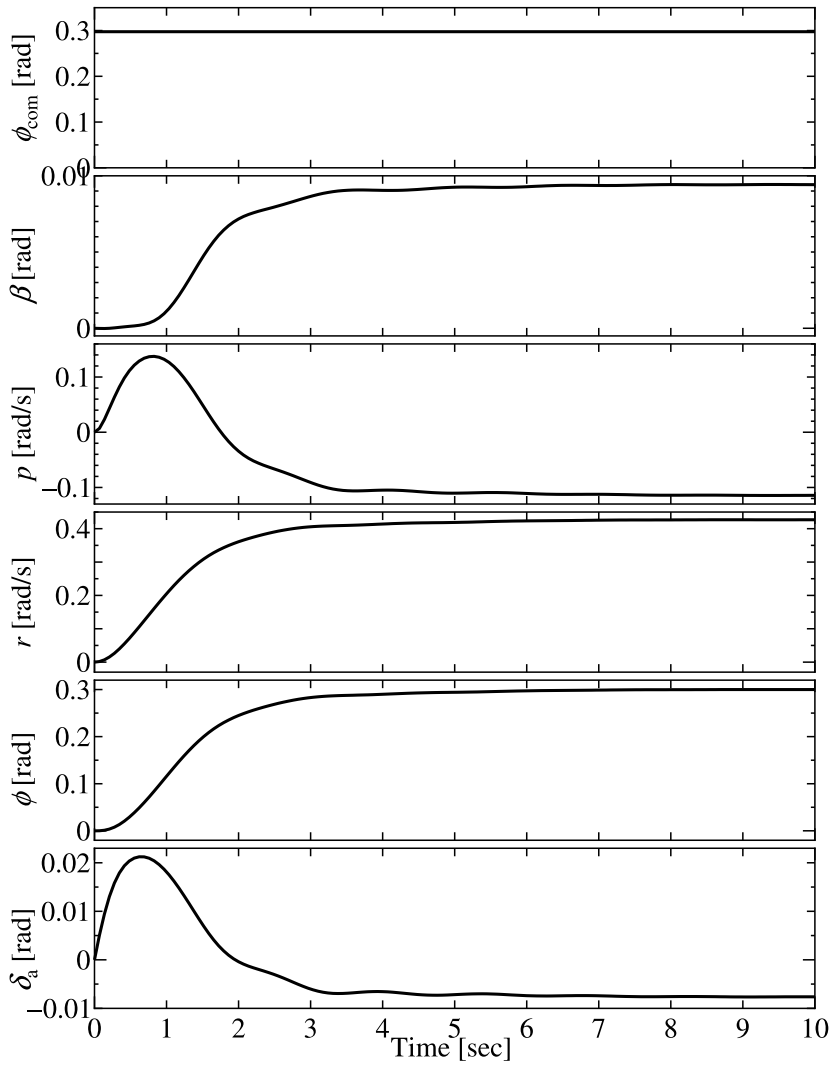

第 15 図 バンク角コマンドのステップ入カに対する応答

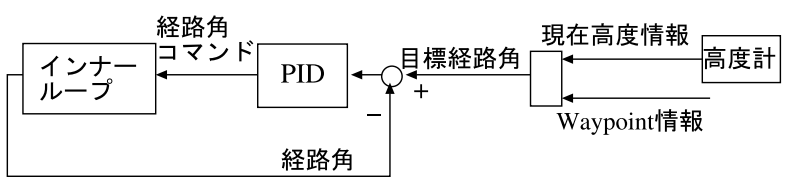

第16図縦の航法誘導系

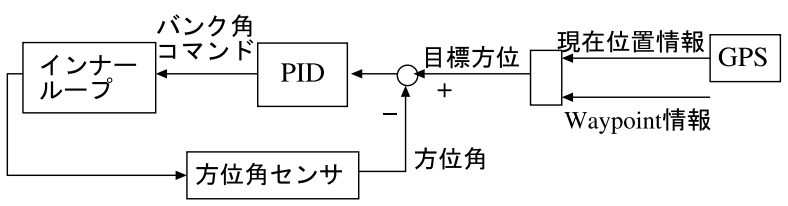

第 17 図 横・方向の航法誘導系

されたウェイポイント情報との誤差を PID コントローラに 入力することで経路角コマンドとバンク角コマンドが決定 される.第 16 図に縦の，第 17 図に横・方向の航法誘導系 ブロック線図を示す．

\section{7. 飛 行 試 験}

設計した航法誘導，制御系コントローラを実装して飛行 試験を行った . 設計した安定化制御器に平衡実現による低 次元化を施し, 双一次変換による離散化を行った後に実装 した。

飛行試験で設定したタスクは手投げで離陸した後，ウェ イポイントWP1〜8 を通過し (第 18 図), 離陸地点に自動 で着陸するものである．指定した目標高度は $15 \mathrm{~m}$ である． 


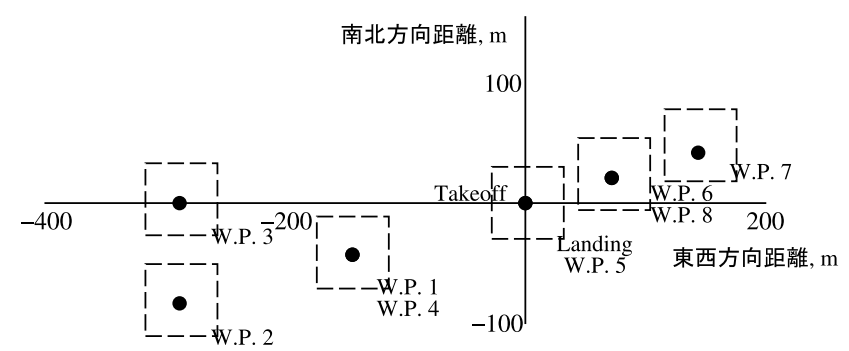

第18図 ウェイポイント位置と座標系

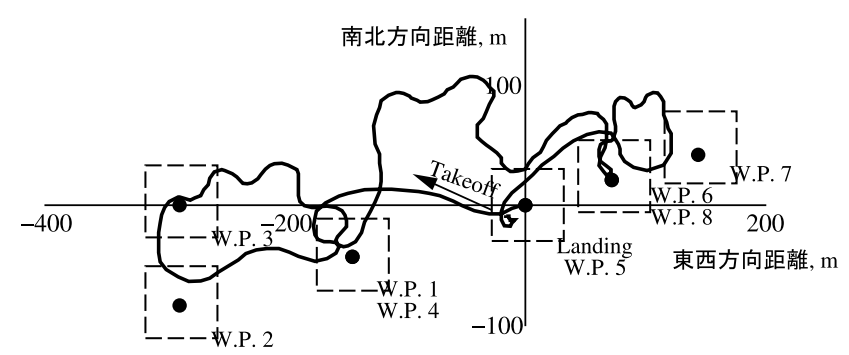

第19図 飛行試験結果

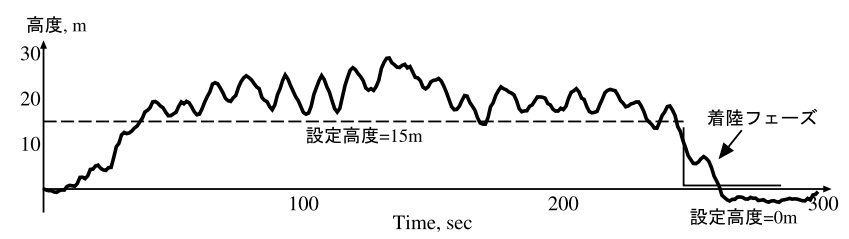

第 20 図飛行試験高度履歴 (気圧高度計による計測)

またウェイポイントを中心とした 1 辺 $60 \mathrm{~m}$ の正方形上空 を通過したら次のウェイポイントに向かう．

天候は晴れで地上の風速は平均約 $2 \mathrm{~m} / \mathrm{s}$ であった . GPS アンテナで測定した飛行履歴と設定したウェイポイントを 第 19 図に, 気圧高度計で記録した高度の時間履歴を第 20 図に示す．これより，設定されたウェイポイントを通過し，
正確に指定した点に着陸していることが確認できる．また ほほ指定した高度を保っていることがわかる．

$$
\text { 8. おわりに }
$$

短時間，短距離のミッションを想定した小型軽量 UAV を 開発した . 機体ダイナミクスを不確かさを含めてモデル化 し $\mu$ 設計法を適用することで, 強いロバスト安定性を備え た安定化制御器を設計した .さらに指示したウェイポイン 卜に沿った飛行を実現する航法誘導系をPID 制御器を用い て構成した .これらの自律飛行システムを新たに開発した 汎用制御基板に実装し, 飛行試験を行った。光の結果指示 したウェイポイントを通過する飛行が達成されていること が確認できた .

この研究の一部は文部科学省科学研究補助金, 基盤研究 (S) , 18100002 を受けてなされた .

\section{参 考 文 献}

1) Jang, J. S. and Tomlin, C. J.: Autopilot Design for the Stanford DragonFly UAV: Validation through Hardware-in-theLoop Simulation, AIAA Paper 2001-4179, 2001.

2) Johnson, E. N., Turbe, M. A., Wu, A. D., Kannan, S. K. and Neidhoefer, J. C.: Flight Test Results of Autonomous Fixed-Wing UAV Transitions to and from Stationary Hover, AIAA Paper 2006-6775, 2006.

3) 穂積弘毅, 牧 緑, 鈴木教雄, 田屋惠唯, 武居秀雄: JAXA 多 目的小型無人機について, 第 43 回飛行機シンポジウム講演集, 2005, pp. 448-451.

4) 宇田川直彦, 古川 徹, 田辺安忠: 携帯型飛行体 $60 \mathrm{~cm}$ 級実験機 システムについて , 日本航空宇宙学会誌, 54 (2006), pp. 37-40.

5) Etkin, B.: Dynamics of Flight, John Wiley \& Sons, Inc., Hoboken, 1959, pp. 94-188.

6) 加藤寛一郎, 大屋昭男, 柄沢研治 : 航空機力学入門, 東京大学出 版会, 東京, 1982, pp. 51-110.

7) 細江繁幸, 荒木光彦 : 制御系設計一 $H_{\infty}$ 制御と关の応用一, 朝 倉書店，東京，1994, pp. 110-133.

8) The MathWorks, Inc., Robust Control Toolbox version 3.0, 2004. 